مقاله يخوهشى

مجله دانشگاه علوم يزشكى رفسنجان

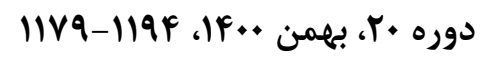

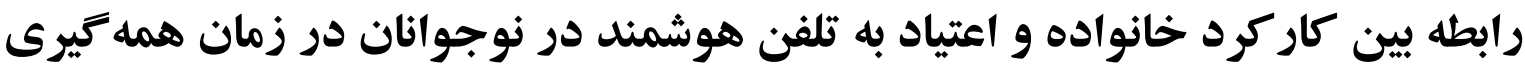

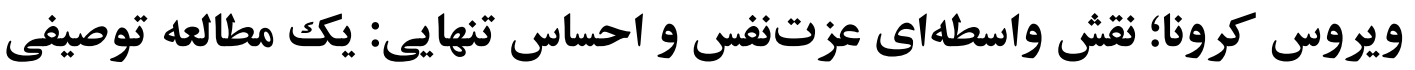

\section{سلمان زارعى'، خديجه فولادوند'}

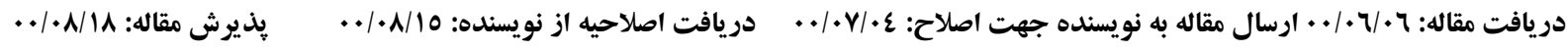

زمينه و هدف: يزوهشها تأييد كردهاند كه كاركرد خانواده با اعتياد به تلفن هوشمند در نوجوانان رابطه دارد. با اين حال، اطلاعات زيادى در مورد ساز و كار واسطهاى اين رابطه خصوصاً در زمان همهَيرى كرونا وجود ندارد. از اينرو، هدف يزوهش تهش حاضر تعيين نقش واسطهاى عزت نفس و احساس تنهايى در رابطه بين كاركرد خانواده و اعتياد به تلفن هوشمند در زمان

$$
\text { همه گيرى كرونا بود. }
$$

مواد و روشها: يزوهش حاضر از نوع توصيفى بود. از جامعه دانشآموزان يسر دوره دبيرستان منطقه fl شهر تهران در سال

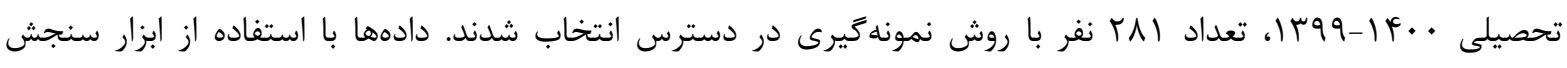
خانواده، مقياس عزت نفس Rosenberg، مقياس استفاده مفرط از تلفن همراه، و ويرايش سوم مقياس احساس تنهايى كاليفرنيا گردآورى و با آزمون همبستكى Pearson و مدلسازى معادلات ساختارى تحليل شد.

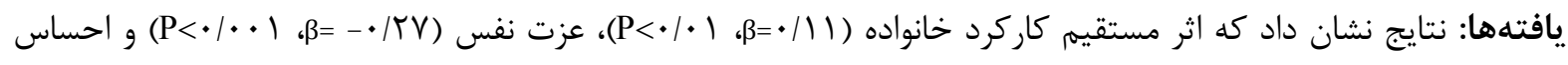

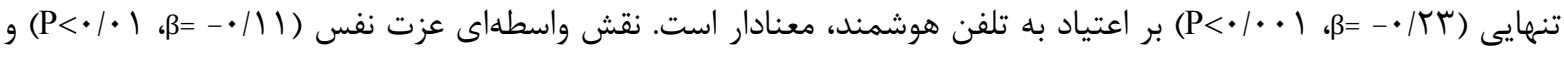

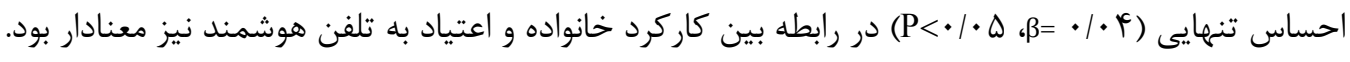
نتيجهَّيرى: اين مطالعه نشان داد نوجوانانى كه در جو خانوادَى بهترى زندكى مى كنند، داراى عزت نفس بالاتر و احساس تنهايى كمتر هستند و احتمال اعتياد به تلفن هوشمند در آنان كمتر است. بنابراين بيشنهاد مىشود متخصصان بالينى حوزه اعتياد اينترنتى، در برنامههاى بيش گَيرانه و مداخلات درمانى استفاده كنند. وازههاى كليدى: اعتياد به تلفن هوشمند، خانواده، احساس تنهايى، عزت نفس، نوجوان

$$
\text { 1- (نويسنده مسئول) استاديار مشاوره، كروه روانشناسى، دانشگاه لرستان، خرم آباد، ايران }
$$

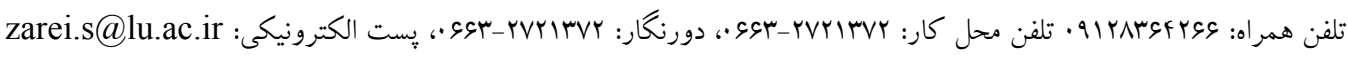

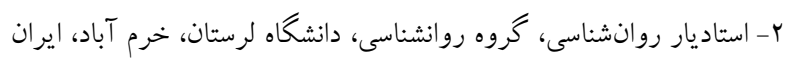


• 111 عوامل فردى و خانود گى در اعتياد به تلفن هوشمند

نحوه تأثير كاركرد خانواده بر رشد اعضاى آن را بررسى مقدمه مى كنند [ [1 -•1]. شواهد يزوهشى نشان مىدهند رابطه مستقيمى بين كاركرد خانواده و اعتياد به تلفن هوشمند وجود دارد [ [1 []. به علاوه، ادراك نوجوانان از كاركرد خانواده مىتواند اعتياد آنها به تلفن هوشمند را ريشبينى كند. مطالعات فراتحليل نيز حاكى از نقش كاركرد خانواده بر رشد اعتياد به تلفن هوشمند در نوجوانان است [سار]. لذا، اين فرضيه مطرح مىشود كه نوجوانان مبتلا به اعتياد به تلفن هوشمند در كاركرد خانواده نمره كمترى مى با وجود اين، نوجوانان گيرندههاى منفعل در برابر محرى محيطى نيستند و ويزَگىهاى فردى نيز در شكل اعتياد به تلفن هوشمند مههم تلقى مىشوند [ع] [ ]. در همين راستا، برخى از يزوهش

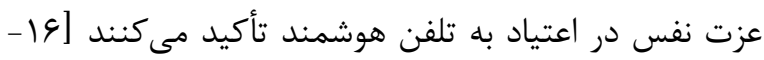
ها]. مدل شناختى -رفتارى اعتياد به اينترنت Davis مطرح مى كند عزت نفس پايين برخى از نوجوانان را مستعد بروز شناختها و رفتارهاى ناسازگار مى كند كه مىتواند منجر به رفتارهاى منفى از جمله اعتياد به تلفن هوشمند شود [11 IV IV عزت نفس هايين منجر به كاهش اعتماد به نفس مىشود كه اين امر ممكن است باعث رفتارهاى يرخطر از جمله اعتياد به تلفن هوشمند شود [ [؟-9 1]. از سوى ديكر، خانواده مكان مهمى براى رشد عزت نفس است. بر اساس شواهد يروهشى، كاركرد مطلوب خانواده مىتواند باعث افزايش عزت نفس و كاهش احتمال اعتياد به تلفن هوشمند شود [rr-Ir]]. بر اين اساس، اين فرض مطرح مىشود كه

بسيارى از كشورها براى كنترل سريع شيوع ويروس كرونا، محدوديتهاى از قبيل در خانه ماندن و فاصلهَذارى اجتماعى را اعمال كردند و افراد را به مطالعه، خريد و كار آنلاين در خانه تشويق كردند [1]]. بررسىهاى اخير نشان مىدهد استفاده از تلفنهاى هوشمند در بين گروهاى سنى مختلف در همه گيرى ويروس كرونا رشد جشمَّيرى داشته است و باعث بروز مشكلى تحت عنوان اعتياد به تلفن هوشمند شده است [ـ-r]]. بر اساس شواهد يزوهشى، اعتياد به تلفن هوشمند با اختلال در خواب و علائم افسردگى در نوجوانان رابطه دارد [ـ-[]]. بر اساس نظريه جبرانى، نوجوانان ممكن است براى اجتناب و تسكين هيجانهاى منفى به استفاده از تلفنهاى هوشمند روى آورند [ع]. بنابراين، با توجه به اثرات منفى اعتياد به تلفن هوشمند در زمينههاى مختلف خانوادگى، اجتماعى و تحصيلى [V] در نوجوانان توجه به عوامل اثر حذار بر آن ضرورى است. برخى از يزوهش همسالان و محيط اجتماعى بر استفاده از فناورى تلفن هوشمند نوجوانان تأثير دارد [A]. در بين بسيارى از يزوهشها نقش اساسى خانواده در اعتياد به تلفن هوشمند را نشان دادهاند [9]. با اين وجود، اين يزوهشها فقط بر جَكونكى تأثير والدين بر فرزندان متمركز شدهاند و يك تعامل يك طرفه را مورد بررسى قرار دادهاند. اكنون بيشتر يزوهش گران به خانواده به عنوان يك سيستم نكاه مى كنند و 
ضرورت دارد يزوهشهاى بيشترى در زمينه عوامل اثر گذار بر اعتياد به تلفن هوشمند انجام شود. بر اين اساس، هدف يزوهش حاضر اين است كه در قالب يك مدل نقش واسطهاى عزت نفس و احساس تنهايى در رابطه بين كاركرد خانواده با استفاده مشكلزا از تلفن هوشمند به محك آزمون كذاشته شود. در همين راستا، مدل مفهومى يزوهش حاضر در شكل ا ارائه شده است.

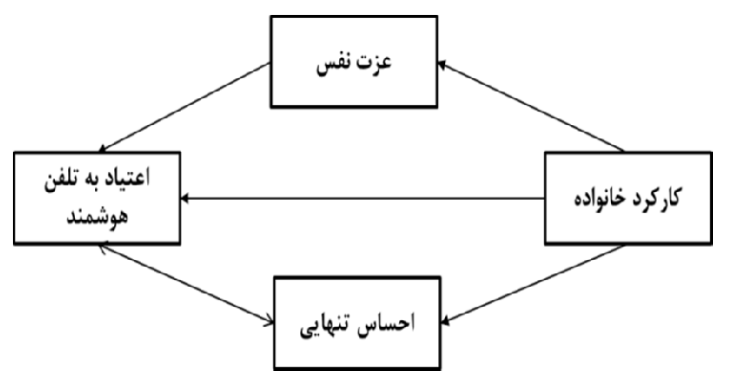

شكل I - ملدل مغهومى نقش ميانجى عزت نقس و احساس تنهايی در رابطه كاركرد خانواده با اعتياد به تلفن هوشمند

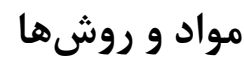

يزوهش حاضر توصيفى بود كه با استفاده از تحليل مسير انجام شد. جامعه آمارى يزوهش دانشآموزان يسر دوره دوم متوسطه منطقه fl شهرستان تهران در سال تحصيلى

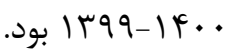

جهت تعيين حجم نمونه بر اساس ديدكاه Kline كه عنوان مى كند در مدل يابى معادلات ساختارى حجم نمونه مورد قبول بايد حداقل ه/ T و حداكثر ه برابر تعداد گويهها يا سؤالات ابزارهاى اندازهخيرى باشد [•r] در يزوهش حاضر با احتساب مجموع سال شود كه در نهايت به دليل ريزش احتمالى نمونه تعداد ...
عزت نفس ممكن است واسطه رابطه بين كاركرد خانواده و اعتياد به تلفن هوشمند باشد. احساس تنهايى نيز مىتواند عامل مهمى در شكل وابستگى به تلفن هوشمند در نوجوانان باشد جرا كه در اين دورة حساس، نوجوانان از طريق يذيرش گروهى به دنبال كسب احساس تعلق هستند [سז]. نياز به صميميت با همسالان ممكن است باعث شود كه آنها به ابزارهاى مختلف از جمله تلفن هوشمند روى آورند [rY]. بر اساس شواهد يزوهشى، افراد معتاد به تلفن هوشمند در روابط اجتماعى، خود بيكانكى را تجربه مى كنند و از تنهايى عاطفى

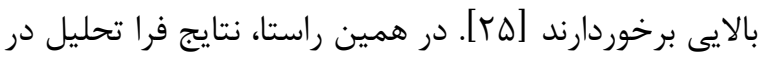
r T كشور نشان مىدهد بين احساس تنهايى و اعتياد به تلفن هوشمند رابطه معنادارى وجود دارد [عr]. علاوه بر اين، كاركرد ضعيف خانواده ممكن است منجر به احساس تنهايى در افراد شده، جستجوى حمايت عاطفى به صورت آنلاين را افزايش داده و سرانجام باعث اعتياد به تلفن هوشمند شود [rV، [Y]] بنابراين، اين فرضيه مطرح مىشود كه احساس تنهايى مىتواند در رابطه بين كاركرد خانواده و اعتياد به تلفن هوشمند نقش واسطه داشته باشد. در مجموع، استفاده بيش از حد يا كنترل نشده از تلفن هوشمند پِيامدهاى منفى زيادى در يى خواهد داشت و حتى سبب بروز اختلالهاى روانشناختى يِيجيدهتر خواهد شد [Y^]. بنابراين، با توجه به شيوع اعتياد به تلفن هوشمند در

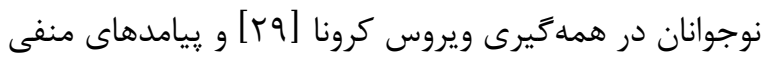
آن در ابعاد مختلف فردى، اجتماعى و تحصيلى نوجوانان، 
I I ا عوامل فردى و خانود گى در اعتياد به تلفن هوشمند

در اين مطالعه ابزار گردآورى دادها شامل سه گرسشنامه زير بود كه به روش خودگزارشدهى توسط شركتكنندگان

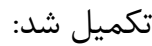

1 - ابزار سنجش خانواده (Family Assessment Device):

ابزار سنجش خانواده يك ابزار •9 سؤالى است كه بنا بر الكوى كاركرد خانواده McMaster توسط Epstein و همكاران در سال س1919 تدوين شده است [اسץ]. اين ابزار در خرده مقياسهاى حل مسئله، روابط، نقشها، پاسخگويى عاطفى، مشاركت عاطفى و كنترل رفتارى كاركرد كلى خانواده را مىسنجد. نمرهزارى با استفاده از مقياس رك درجهاى ليكرتى (كاملاً موافق=ا، موافق= ז، مخالف=؟، كاملاً مخالف=| أنجام مىشود. براى به دست آوردن نمره هر خرده مقياس، نمرات همه سؤالهاى هر خردمقياس با هم جمع شده و بر تعداد سؤالهاى آن خرده مقياس تقسيم مىشود. نمرات بالاتر نشاندهنده كاركرد ناسالمتر هستند. اخر · l درصد از موارد يك مقياس ير نشده باشد، نمره مقياس محاسبه نخواهد شد. هريك از اعضاى خانواده كه بيش از ז ا سال سن داشته باشد مىتواند اين ابزار را پاسخ دهد. Epstein و همكاران روايى همزمان و پِيشبين ابزار سنجش خانواده را از طريق همبستگى با مقياس رضايت زناشويى لاك-والاس مورد تدييد قرار دادهاند. همجنين، آنان دامنه ضريب آلفاى كرونباخ خرده مقياسها و كل ابزار را در

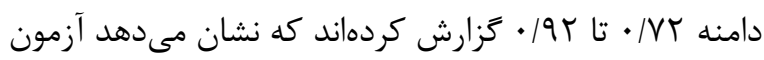
از همسانى درونى نسبتاً خوبى برخوردار است [اس]. Zolfaghari
دانشآموز با استفاده از روش نمونهَيرى در دسترس و بر اساس ملاكهاى ورود به عنوان نمونه نهايى انتخاب شد. ملاكهاى ورود به يزوهش شامل: () رضايت معلم و

دانشآموز براى شركت در يزوهش و ؟) دامنه سنى ها تا 11 سال بود و تنها ملاك خروج از يزوهش داشتن سابقه بيمارى جسمانى و روانشناختى خاص (بنا بر خود زَارشى

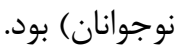
روش گردآورى دادهها در اين مطالعه به اين صورت بود كه يرسشنامهها به صورت آنلاين با استفاده از نرمافزار يُرس لاين طراحى گرديد. سيس با همكارى سرگروه كانالهاى مختلف نوجوانان (معلمان نوجوانان) در شبكههاى اجتماعى واتساب و تلكرام لينك يرسشنامهها به انضمام فرم رضايت آكاهانه در اختيار آنها قرار داده شد و از اعضاى گروه خواسته شد با توجه به ملاكهاى ورود مطرح شده و در صورت تمايل به همكارى به קرسشنامهها پاسخ دهند. ملاحظات اخلاقى اعم از مطلع بودن شركتكنندكان از روند يزوهش و محرمانه ماندن اطلاعات شركتكنندگان نيز در يزوهش رعايت شده است. همجنين تمامى معيارهاى رعايت اخلاق در يزوهش كه در مطالعه حاضر موضوعيت داشت همسو با بيانيه هلسينكى رعايت شده است. مطالعه

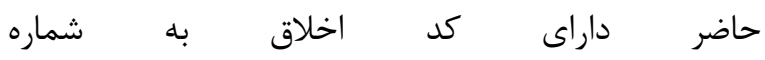
IR.IAU.TMU.REC.1399.015 از شوراى تخصصى يزوهش دانشخاه آزاد اسلامى واحد تهران جنوب است. 
1990 به منظور اندازهيرى عزت نفس حرمت كلى و ارزش

شخصى تدوين شده است كه شامل • ا ماده است و پِاسخ به هر ماده آن شامل يك مقياس جهارگزينهاى (از كاملاً موافقم تا كاملاً موافقم) است كه در دامنهاى از صفر تا ب مرتب شده است [هـ]. شيوه نمرهَذارى اين مقياس براى مادههاى ا تا له به صورت مستقيم و براى مادههاى 9 تا • ا برعكس است. دامنه نمره مقياس در محدوده • ا تا ..1 است و نمره بالاتر در اين مقياس نشاندهنده عزت نفس بيشتر است. Rosenberg ضرايب آلفاى كرونباخ مقياس براى زنان را MM|• و براى مردان را AV| • گزارش كرده است [هـ]. روايى اين مقياس در يزوهش Leary از طريق همبستكى با يرسشنامه حرمت خود Coopersmith بررسى شده است كه ضريب 19|• كزارش شده است كه ازاينرو روايى آن تأييد مىشود [عَ]. Mohammadi Attaran همبستخى مقياس حرمت خود Rosenberg با مقياس حرمت خود كوير اسميت برابر با |و|• است. آنان همرجنين اعتبار آزمون با استفاده از ضريب آلفاى كرونباخ و دونيمه سازى مقياس را به ترتيب برابر با و9|• و \$1 • در بين دانشجويان كزارش كردهاند [rv]. در يزوهش حاضر نيز اعتبار مقياس با استفاده از ضريب آلفاى كرونباخ براى كل مقياس برابر با

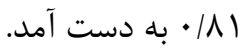
ץ- ويرايش سوم مقياس احساس تنهايى كاليفرنيا (UCLA Loneliness Scale- Version 3) مقياس احساس تنهايى در سال 1999 توسط Russell
اعتبار اين ابزار را با استفاده از روش باز آزمايى براى كل ابزار برابر با 9F/• كزارش كردهاند [rr]. در يزوهش حاضر نيز اعتبار كل با استفاده از ضريب آلفاى كرونباخ برابر با V9/•

به دست آمد.

r- مقياس استفاده مفرط از تلفن همراه ( Cell-phone Jenaro Over- use Scale

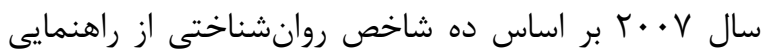
تشخيص و طبقهبندى اختلالات روانى طرح شده است [سץ]. اين مقياس شامل بr سؤال است و خرده مقياس ندارد. نمرهذذارى هر سؤال بر روى يك يِيوستار ليكرت شش

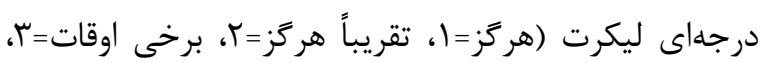
اغلب=أ تقريباً هميشه=ه، هميشه=و) تنظيم شده است و كسب نمره بالاتر حاكى از استفاده مشكلزاو مفرط از تلفن هوشمند است. دامنه نمره كلى مقياس سץ تا ربا است. و همكاران همسانى درونى مقياس به روش آلفاى Jenaro كرونباخ را براى نمونه از دانشآموزان دختر و يسر AV/• كزارش كردهاند [سب]. در ايران روايى اين مقياس در هنجاريابى آن روى نمونهاى از دانشجويان توسط Golmohhamadian همسانى درونى يرسشنامه را با استفاده از روش باز آزمايى

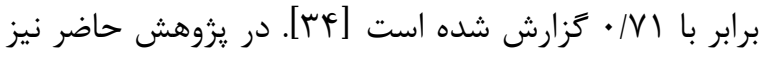
ميزان קايايى مقياس به روش آلفاى كرونباخ برابر \&\/• به

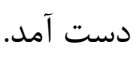
r- مقياس عزت نفس روزنبرگ ) Rosenberg SelfEsteem Scale 
عنوان داده يرت مشخص و از روند يزوهش حذف شد و در نهايت دادههاى مربوط به |YN نفر با استفاده از آمار توصيفى (ميانخين، انحراف استاندارد، كجى و كشيدگى) و آمار استنباطى (ضريب همبستكى Pearson، مدل يابى معادلات ساختارى و آزمون بوت استراب) با استفاده از نرمافزارهاى آمارى SPSS نسخه سץ و Amos نسخه اب در سطح معنادارى ه درصد تحليل شد. نتايج در بررسى ويزگى هاى جمعيت شناختى نشان داد كه ميانكين و انحراف استاندارد سن نوجوانان به ترتيب برابر با r/ه/q و I/r/ سال بود. در ادامه در جدول I اطلاعات توصيفى و وضعيت نرمال بودن توزيع نمرات آزمودنىها در متغيرهاى يزوهش ارائه مىشود. جدول ل، در كنار يرداختن به ميانخين و انحراف استاندارد نمرات آزمودنىها نشان مىدهد كه كجى توزيع نمرهها در دامنه I+ و 1- و كشيدگى در دامنه r+ و r- قرار دارد و همرجنين نتايج آزمون Kolmogorov-Smirnov نيز نشان داد كه سطح معنادارى آماره Z بزرگتر از هـ • • است. بنابراين بر اساس اين آمارهها نرمال بودن توزيع نمرات تأييد مىشود.
ساخته شده است كه شامل •r سؤال است [مץ]. اين مقياس •ا سؤال منفى و •ا سؤال مثبت دارد و بر اساس مقياس جهاردرجهاى ليكرت به هرگز ( نمره () تا هميشه (نمره \&) نمرهگذارى مىشود كه سؤالات ا، ه، \&، 9، •.، ه1، 19، 19 و · r معكوس نمرهگذارى مىشوند. دامنه نمره كلى مقياس •r تا •N است كه نمره بالاتر بيانكر شدت بيشتر احساس تنهايى است. Russell روايى همخرايى مقياس را از طريق همبستكى آن با ساير ابزارهاى اندازهيرى احساس تنهايى از جمله مقياس احساس تنهايى NYU و و يايايى مقياس به روش باز آزمايى در فاصله زمانى 1 ا ماه

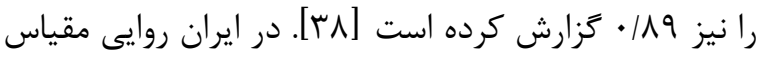
توسط Khoshdel daryasari و همكاران تأييد شده است و پايايى مقياس با استفاده از ضريب آلفاى كرونباخ N1/· و با استفاده از ضريب باز آزمايى را \9/. كزارش شده است [qץ]. در يزوهش حاضر نيز اعتبار مقياس با استفاده از ضريب آلفاى كرونباخ براى مقياس برابر با \&\|• به دست

يس از اجراى يرسشنامهها تعداد 19 ״رسشنامه با استفاده از فاصله مهالانوبيس (Mahalanobis distance) به 


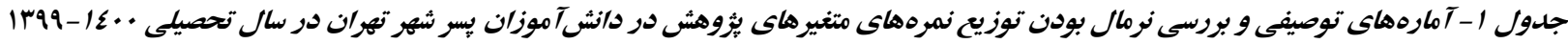

\begin{tabular}{|c|c|c|c|c|c|c|}
\hline \multicolumn{2}{|c|}{ Kolmogorov-Smirnov } & \multirow{2}{*}{ كشيدَى } & \multirow{2}{*}{ كجى } & \multirow{2}{*}{ انحراف } & \multirow{2}{*}{ ميانگين } & \multirow{2}{*}{ شتغاخصها } \\
\hline مقدار p & آماره Z & & & & & \\
\hline .1 .99 & $\cdot 1 \cdot \vee 9$ & - IATS & $1 / r \cdot V$ & $11 / \mathrm{rr}$ & $114 / 09$ & كار كرد خانواده \\
\hline$\cdot / \cdot \Delta T$ & .1 .91 & 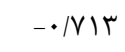 & $-1 / \cdot V T$ & $r / \Delta \mid$ & $19 / \pi V$ & عزت عنس \\
\hline .1 .91 & $\cdot|\cdot \wedge|$ & - &.$- / 9 k T$ & $9 / 1 V$ & FT/G9 & احساس تنهايى \\
\hline.$/ .95$ & r./. & $\cdot 19 \cdot 9$ & $\cdot \mid \Delta \wedge r$ & 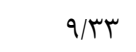 & GN/VD & اعتياد به تلفن هوشمند \\
\hline
\end{tabular}

حاصل شد. نرمال بودن توزيع دادهها در جدول ا مورد بررسى قرار گرفت. براى حجم نمونه اغلب مؤلفان نمونه بالاتر از .ب نفر را براى تحليل مسير مناسب دانستهاند كه بر اين اساس حجم نمونه ( I نفر ) شرط كفايت نمونه را برقرار مىسازد. همخطى جندكانه بين متغيرهاى :زوهش مفروضه ديكر است كه با استفاده از شاخص تحمل و عامل تورم واريانس مورد بررسى قرار گرفت كه نتايج حاصل از بررسى همخطى جندكانه در جدول r نشان مىدهد كه آماره تحمل (بزرىتر از • |/•) و عامل تورم واريانس (كمتر

$$
\text { از • ( ) در دامنه يذيرش قرار دارند. }
$$

جدول Y به ماتريس همبستخى بين متغيرهاى يزوهش مى يردازد. نتايج نشان مىدهد كه بين كاركرد خانواده و احساس تنهايى با اعتياد به تلفن هوشمند رابطه مثبت معنادار و بين عزتنفس با اعتياد به تلفن هوشمند رابطه منفى معنى دار وجود دارد. با توجه به تأييد ارتباط معنادار بين متغيرها با يكديكر، امكان بررسى نقش واسطهاى عزت نفس و احساس تنهايى در رابطه بين كاركرد خانواده و اعتياد به تلفن هوشمند فراهم است. در ادامه به منظور بررسى مدل يزوهش از تحليل مسير استفاده شد. پِيش از اجراى اين آزمون از برقرارى مفروضههاى اساسى آن (حجم نمونه، نرمال بودن توزيع دادهها، همخطى جند

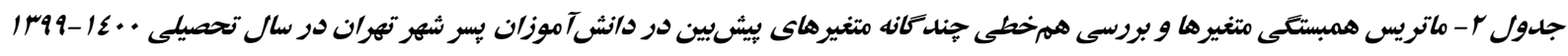

\begin{tabular}{|c|c|c|c|c|c|c|}
\hline \multicolumn{2}{|c|}{ شاخصهاى همخطى جند } & \multicolumn{3}{|c|}{ ضرايب همبستخى } & \multirow[b]{2}{*}{ (1) } & \multirow{2}{*}{ شاخصهاى آمارى } \\
\hline عامل تورم & آماره تحمل & $(\boldsymbol{f})$ & $(\Psi)$ & $(Y)$ & & \\
\hline I/TFT & $\cdot / r \cdot r$ & & & & 1 & (1) كاركرد خانواده \\
\hline $\boldsymbol{F} / \cdot \boldsymbol{\mu}$ & . I9Y9 & & & 1 & $\cdot / \uparrow \Delta * *$ & (ץ) عزت نفس \\
\hline$r / \boldsymbol{T} \cdot \Lambda$ & $\cdot|\Delta| V$ & & 1 & $-\cdot / \Delta V^{* *}$ & $\cdot / r V^{* *}$ & (ץ) احساس تنههايى \\
\hline- & - & 1 & $\cdot /$ rF** & $-\cdot / r \Lambda * *$ & $\cdot|r| * *$ & (F) اعتياد به تلفن هوشمند \\
\hline
\end{tabular}


11149 عوامل فردى و خانودگى در اعتياد به تلفن هوشمند

آزادى (Chi-squared/freedom) كمتر از س، شاخص برازش تطبيقى (Comparative Fit Index) و شاخص نيكويى برازش (Goodness of Fit Index) بزرگتر از • 9/• و ريشه ميانگين مجذور خطا ( Equare Error of (Approximation است [ـ[]. لذا، شاخصهاى به دست آمده نشان مىدهند كه دادهها با مدل مفهومى مد نظر يروهش براى روابط

$$
\text { متغيرهاى برازش دارد. }
$$

شكل r، مدل يروهش بر اساس ضرايب استاندارد شده (ß) را نشان مىدهد. با توجه به شكل r، كاركرد خانواده، عزتنفس و احساس تنهايى در مجموع 19 درصد از واريانس اعتياد به تلفن هوشمند را تبيين مى كنند. بررسى شاخصهاى برازش مدل نشان مىدهد كه تمامى شاخصهاى برازش به دست آمده از مطلوبيت بالايى برخوردارند، زيرا مطابق ديدگاه Kline در خصوص مهممترين شاخصهاى مربوط به برازش مدل، نسبت خى دو به درجه

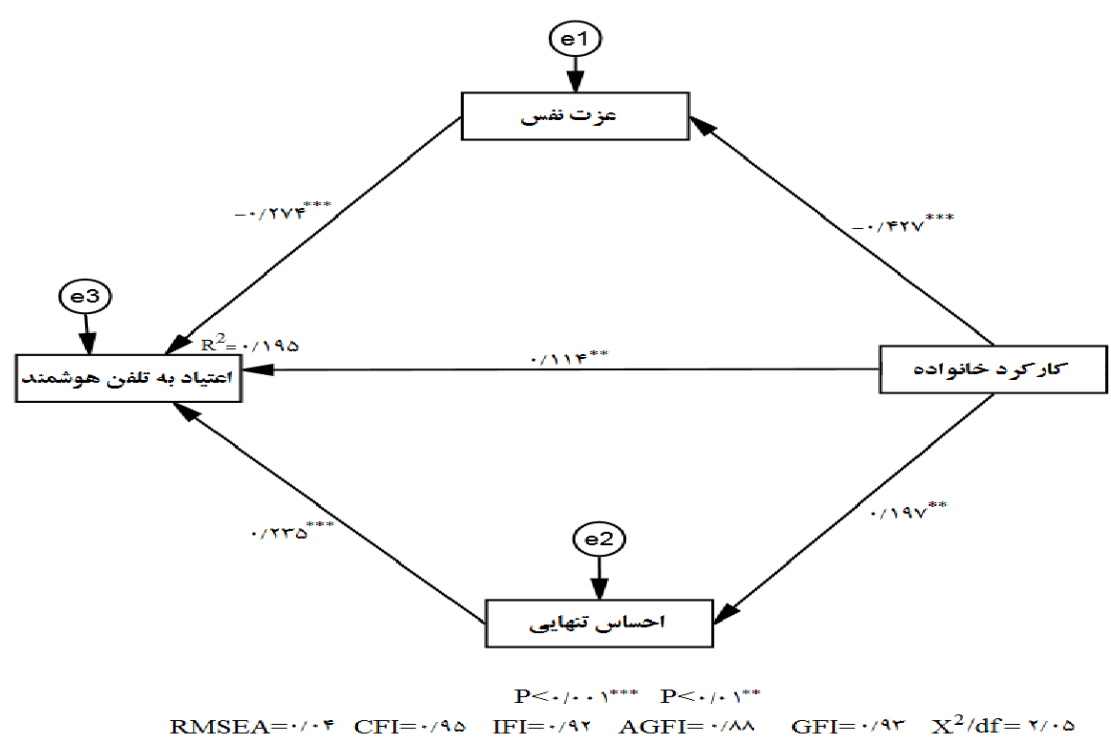

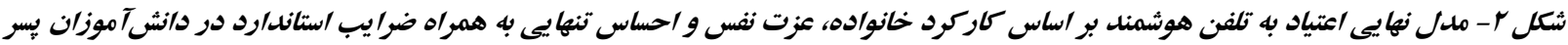

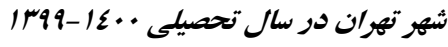

به اندازه مقدار بتاى آن متغير تغيير مىكند و مقدار نسبت بحرانى 9 • نشان مىدهد كه اين مسير در سطح P معنادار است.نتايج نشان داد اثر مستقيم كاركرد خانواده بر احساس تنهايى مثبت است كه ميزان بتا (ß) 19V / • نشان مىدهد با يك واحد تغيير در كاركرد خانواده مقدار احساس تنهايى به اندازه مقدار بتاى آن متغير تغيير

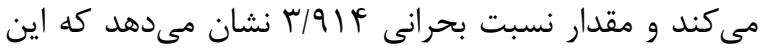

با توجه به برازش مناسب مدل تخمين استاندارد مسيرهاى مستقيم و غيرمستقيم مدل در جدول ب ززارش شده است.

بر اساس مسيرهاى آزمون شده در مدل (شكل ؟) و نتايج جدول س، مشاهده مىشود اثر مستقيم كاركرد خانواده بر عزتنفس منفى است كه ميزان بتا (ß) IFV •- نشان مىدهد با يك واحد تغيير در كاركرد خانواده مقدار عزت نفس 
ميانجى گرى عزتنفس (1/|•- =

هوشمند منفى است و اين ضريب مسير غيرمستقيم در

سطح اطمينان 99/ • معنادار است، زيرا نتايج آزمون بوت

استراب نشان داد كه حد يايين و حد بالاى اين ضريب مسير

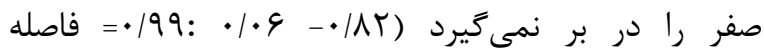

اطمينان). در نهايت نتايج نشان مىدهد كه اثر غيرمستقيم

كاركرد خانواده از طريق ميانجى گرى احساس تنهايى (4 • •

( ) بر اعتياد به اينترنت مثبت است و اين ضريب مسير

غيرمستقيم در سطح اطمينان ه9/• معنادار است، زيرا نتايج

آزمون بوت استراب نشان داد كه حد پايين و حد بالاى اين

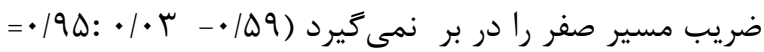

$$
\text { فاصله اطمينان). }
$$

مسير در سطح l P< معنادار است (لازم به ذكر است در خصوص كاركرد خانواده نمره بالاتر نشانگر كاركرد ضعيف خانواده است). در بخش ديگر نتايج نشان داد كه اثر

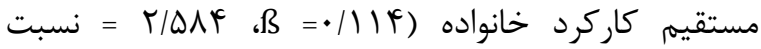

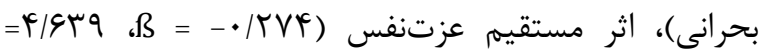
نسبت بحرانى)، و اثر مستقيم احساس تنهايى (هـ/ ץ • F / = نسبت بحرانى ) بر اعتياد به تلفن هوشمند معنادار است كه مقادير بتا (ß) هر مسير نشان مىدهد با يك واحد تغيير در هر كدام از اين سه متغير مقدار اعتياد به تلفن هوشمند به اندازه مقدار بتاى آن متغير تغيير مى كند و مقدار نسبت بحرانى هر كدام از مسيرها نشان مىدهد كه اين مسيرها در سطح I P P Pعنادار هستند. همجنين، نتايج نشان مىدهد كه اثر غيرمستقيم كاركرد خانواده از طريق

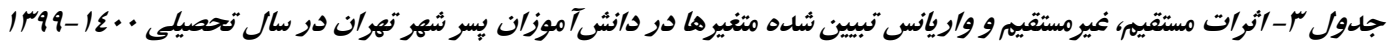

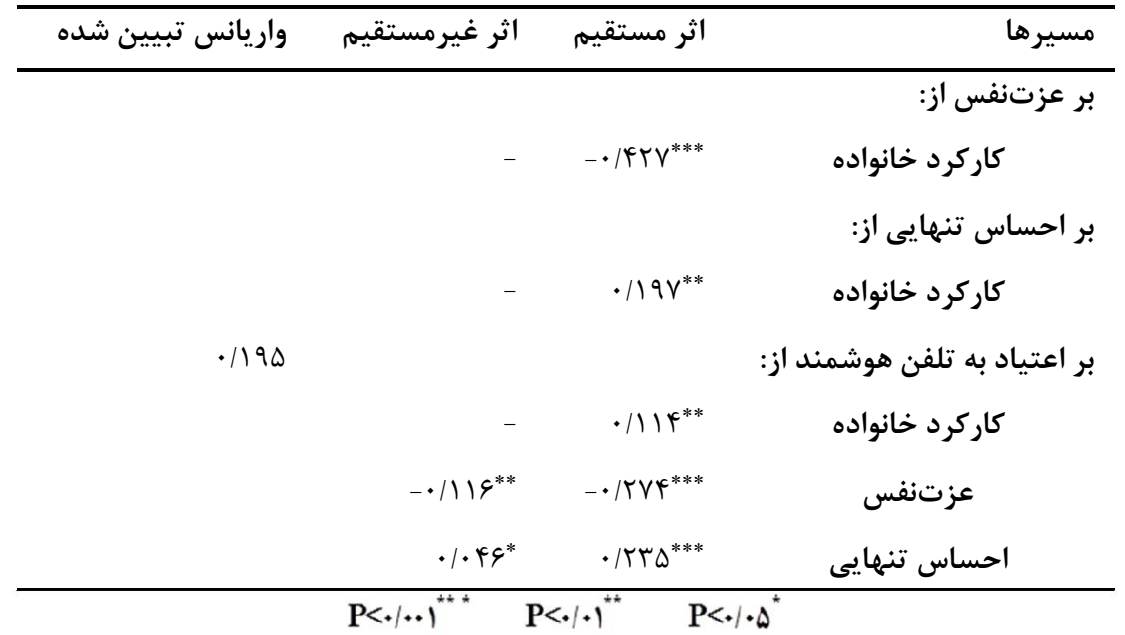

افزايش مىيابد. نتايج اين بخش از يثوهش با نتايج مطالعات بحث

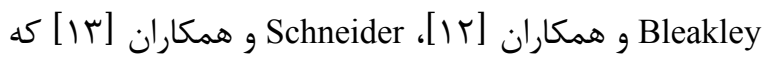
نتايج نشان داد كاركرد خانواده بر اعتياد به تلفن هوشند نشان مىدهند كاركرد بهتر خانواده باعث كاهش احتمال اعتياد به تلفن هوشمند مىشود، همسو است. همجنين، در اثر مثبت مستقيم دارد به اين معنا كه هر جه كاركرد خانواده ضعيفتر باشد اعتياد به تلفن هوشمند نوجوانان 
اتخاذ كنند [• []، كه مطابق با مدل شناختى-رفتارى اعتياد به اينترنت Davis مىتوان مطرح كرد عزتنفس يايين نوجوانان را مستعد نشان دادن شناختها و رفتارهاى ناساز كار مى كند كه منجر به نتايج منفى از جمله اعتيادهاى رفتارى از قبيل اعتياد به تلفن هوشمند شود [IV] ل در كنار موارد مطرح شده، در تبيين اين نتايج قابل ذكر است كاركرد نامطلوب خانواده مىتواند در افراد احساس شايستگى شخصى و كارآمدى كه از ابعاد مهم عزتنفس هستند را كاهش دهد و در نتيجه اين افراد در مواجهه با جالشهاى زندگى بجاى اتخاذ راهبردهاى انطباقى بيشتر آسيبيذير باشند. در تبيينى ديگر مىتوان مطرح كرد كه كاركرد سالم خانواده مخصوصاً ياسخ گويى عاطفى باعث ميىشود افراد احساس كنند كه دوستداشتنى هستند و اين احساس دوستداشتنى بودن در شكلگيرى عزتنفس عامل بسيار مهمى است كه مىتواند از بروز مشكلات رفتارى متعددى از جمله اعتياد به تلفن هوشمند جلوكيرى كند [ [ []. در نهايت نتايج نشان داد كه كاركرد خانواده از طريق احساس تنهايى بر اعتياد به تلفن هوشمند نوجوانان اثر غيرمستقيم دارد و كاركرد نامطلوب خانواده مىتواند با افزايش سطح احساس تنهايى نوجوانان باعث گرايش آنها به اعتياد به تلفن هوشمند شود. نتايج اين بخش از يزوهش با Shi Shi همكاران [Yl] و Lian و همكاران [rV] همسو است. در تبيين اين يافته مىتوان بيان داشت كه نوجوانان يسر گرايش بين فردى بيشترى دارند و به روابط بين فردى خود حساستر هستند [بr]، ازاينرو اگر كاركرد خانواده خود را مطلوب ارزيابى نكنند ممكن است در صورت
همسويى با يزوهش حاضر، يزوهش گران به ويزَى هاى منفى كاركرد نظام خانواده از قبيل فاصله عاطفى زياد، فضاى تنش در خانواده و ناتوانى در حل مسئله اشاره مى كنند كه با اختلالهاى رفتارى از قبيل اعتياد به تلفن هوشمند در ارتباط هستند [9]. در تبيين اين يافته مىتوان بر اساس نظريه سيستمى بومشناختى بيان داشت كه گرايش به رفتارهاى اعتيادى زمانى نشان داده مىشود كه ييوند بين فرد و خانواده ضعيف شود [V]]. در واقع از آنجايى كه كاركرد خانواده يك جنبه مههم محيط خانواده در حفظ سلامت جسمانى، اجتماعى و هيجانى افراد است، آنجه درون خانواده اتفاق مىافتد در كنار جُكونكى كاركرد آن مىتواند يك عامل مهم در ايجاد انعطافيذيرى و كاهش خطرات مرتبط با رويدادها و شرايط نامناسب در محيطهاى مختلف و در نتيجه كاهش كرايش به رفتارهاى اعتيادى از قبيل اعتياد به تلفن هوشمند باشد [1 ا]]. در بخش ديخر نتايج نشان داد كه كاركرد خانواده از طريق عزتنفس بر اعتياد به تلفن هوشمند نوجوانان اثر غيرمستقيم دارد و كاركرد نامطلوب خانواده مىتواند با كاهش سطح عزت نفس نوجوانان باعث گرايش آنها به اعتياد به تلفن هوشمند شود. نتايج اين بخش از يزوهش با مطالعات Yao و همكاران [19] و Shi و همكاران [r| همسو است. در تبيين اين يافته مىتوان بيان داشت كه فضاى نامطلوب خانواده و سبكهاى فرزند يرورى ناكارآمد والدين باعث مىشود كه سطح عزتنفس افراد بهطور مطلوبى شكل نكَيرد و در نتيجه اين افراد ممكن است نسبت به رخدادهاى منفى خانوادگى كذشته خود يك نكرش منفى 
براى دستيابى به روابط على استفاده شود. دوم، دانش آموزان دوره اول متوسطه به دليل شرايط مدرسه در اين مطالعه قرار نداشتند، اين باعث شد اطلاعات تا حدودى ناقص باشد و نتايج بايد با احتياط تحليل شود. سر انجام، متغييرهاى مهمم جمعيت شناختى از قبيل معدل تحصيلى، سطح تحصيلات والدين، شغل والدين و رتبه تولد در يزوهش حاضر مورد بررسى قرار نخرفتهاند كه نتايج را با محدوديت مواجه مى كند، لذا توصيه مىشود در مطالعات آتى اين متغيرهاى نيز لحاظ شوند.

\section{نتيجهدَيرى}

بر اساس نتايج يزوهش حاضر، كاركرد خانوادگى بهتر با عزتنفس بالاتر، احساس تنهايى كمتر و احتمال كمتر اعتياد نوجوانان گٍر به تلفن هوشمند همراه است. علاوه بر اين، كاركرد خانواده از طريق عزتنفس و تنهايى مىتواند بر اعتياد به تلفن هوشمند اثر بكذارد كه به ما يادآورى مى كند در طول دوره مداخله بيشتر به كاركرد خانواده و ويزخى هاى فردى نوجوانان توجه كنيم. بر اين اساس، اين مطالعه با در نظر كرفتن عوامل محيطى (كاركرد خانواده) و عوامل فردى (نكرش شناختى: عزتنفس و حالت هيجانى: تنهايى) مكانيسم رابطه بين كاركرد خانواده و اعتياد به تلفن هوشمند را مورد بررسى قرار داد، با اين اميد كه بتواند نظريه جامعترى را براى درك اعتياد به تلفن هوشمند و استفاده از آن براى كمك به نوجوانان ارائه كند. علاوه بر اين، نتايج يزوهش حاضر مىتواند با نتاه به كاهش اعتياد به تلفن هوشمند از طريق مشاوره خانواده براى كاركرد بهتر خانواده
عدم تأمين نيازهاى صميمانه ارتباطى در زندگى خانوادگى به سمت جستجوى ارتباط در فضاى ديخرى باشند كه تلفن هوشمند بهراحتى اين امكان را فراهم مىآورد و مىتوان انتظار داشت كه اعتياد به تلفن هوشمند به علت دسترسى آسان به شبكهاى اجتماعى ايجاد شود. همجنين، قابل طرح است كه كاركرد مطلوب خانواده جو خانوادگى بهتر نه تنها بر اعتمادبهنفس تأثير مى گذارد، بلكه بر روند شكل حفظ روابط صميمى تأثير مى گذارد كه مىتواند احساس تنهايى را كاهش دهد [عץ] و در نتيجه امكان جستجوى يشتيبانى از طريق شبكههاى اجتماعى مجازى و در نهايت كاهش احتمال اعتياد به تلفن هوشمند را به دنبال داشته باشد. در تبيين ديكر، قابلطرح است كه اگر حمايت غيرشرطى و پِاسخَّيى هيجانى خانواده محدود و نامناسب باشد اين احتمال بالا مىرود كه افراد سطح خود انتقادگرى و در نتيجه كرايش به انزوا و تنهايى در افراد افزايش يابد [YY]، كه در اين صورت مىتوان انتظار داشت كاركرد مطلوب خانواده كه در آن يذيرش غيرشرطى رخ دهد، مىتواند از طريق افزايش قدرت هيجانى و كاهش انزوايى بين فردى شانس مقابله با اعتياد به تلفن هوشمند در نوجوانان را

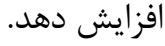

هر يزوهشى داراى محدوديت است در خصوص يزوهش حاضر، ابتدا اين كه نتايج مبتنى بر دادههاى مقطعى است كه نمىتواند ارتباط على و معلولى داشته باشند، بنابراين نتايج بايد باحتياط بررسى شود. لذا يِشنهاد مىشود در تحقيقات آينده از روشهاى متعددى مانند آزمايشى و مطالعه طولى 
• 19 اعوامل فردى و خانودگى در اعتياد به تلفن هوشمند

يزوهش گران بر خود لازم مىدانند كه از مديران، معلمان

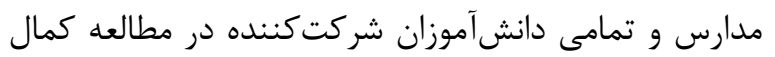

تشكر و قدردانى را داشته باشند.
يا تغيير خودارزيابى و حالت هاى هيجانى از طريق شناخت درمانى مداخله در اين مشكل را دقيقتر كند. تشكر و قدردانى

\section{References}

[1] Xiao H, Zhang Y, Kong D, Li S, Yang N. Social capital and sleep quality in individuals who selfisolated for 14 days during the coronavirus disease 2019 (COVID-19) outbreak in January 2020 in China. Med Sci Monit 2020; 26: e923921.

[2] Gupta K, DSilva MH. Proliferation of social media during the COVID-19 pandemic: a statistical enquiry. JXi'an Univ Archit Technol 2020; 12: 1752-9.

[3] Hamilton J, Nesi J, Choukas-Bradley S. Teens and social media during the COVID-19 pandemic: staying socially connected while physically distant. PsyArXiv 2020; doi: 10.31234/osf.io/5stx4

[4] Brand M, Rumpf HJ, King DL, Potenza MN, Wegmann E. Clarifying terminologies in research on gaming disorder and other addictive behaviors: Distinctions between core symptoms and under- lying psychological processes. Curr Opin Psychol 2020; 36: 49-54.
[5] Busch PA, McCarthy S. Antecedents and consequences of problematic smartphone use: A systematic literature review of an emerging research area. Comput Hum Behav 2020; 114: 106414.

[6] Garfin DR. Technology as a coping tool during the coronavirus disease 2019 (COVID-19) pandemic: implications and recommendations. Stress Heal J Int Soc Investig Stress 2020; 36: 555-9.

[7] Yang J, Fu X, Liao X, Li Y. Association of problematic smartphone use with poor sleep quality, depression, and anxiety: a systematic review and meta-analysis. Psychiatry Res 2020; 284: 112686.

[8] Chaudhury P, Tripathy H. A Study on impact of smartphone addiction on academic performance. Int $J$ Eng Technol 2018; 7: 50.

[9] Lam LT. The Roles of Parent-and-Child Mental Health and Parental Internet Addiction in Adolescent Internet Addiction: Does a Parent-and-Child Gender Match Matter? Front Public Health 2020; 8: 142. 
[10] Bonnaire C, Phan O. Relationships between parental attitudes, family functioningand Internet gaming disorder in adolescents attending school. Psychiatry Res 2017; 255: 104-10.

[11] Kim HJ, Min JY, Min KB, Lee TJ, Yoo S, Relationship among family environment, self-control, friendship quality, and adolescents' smartphone addiction in South Korea: Findings from nationwide data. PloS one 2018; 13(2): e0190896.

[12] Bleakley A, Ellithorpe M, Romer D. The Role of Parents in Problematic Internet Use among US Adolescents. Media Commun 2016; 4(3): 24.

[13] Schneider LA, King DL, Delfabbro PH. Family factors in adolescent problematic Internet gaming: A systematic review. J Behav Addict 2017; 6(3): 321-33.

[14] Blackwell D, Leaman C, Tramposch R, Osborne C, Liss M. Extraversion, neuroticism, attachment style and fear of missing out as predictors of social media use and addiction. Pers Individ Diff 2017; 116: 72.

[15] Apaolaza V, Hartmann P, D’Souza C, Gilsanz A. mindfulness, compulsive mobile social media use, and derived stress: The mediating roles of self-esteem and social anxiety. Cyberpsychol Behav Soc Netw 2019; 22(6): 388-96.

[16] Andreassen CS, Pallesen S, Griffiths MD. The relationship between addictive use of social media, narcissism, and, self-esteem: findings from a large national survey. Addict Behave 2017; 64: 287-93.

Kim E, Koh E. Avoidant attachment and smartphone addiction in college students: the mediating effects of anxiety and self-esteem. Comput Hum Behav 2018; 84: $264-71$.

[18] Wang P, Zhao M, Wang X, Xie X, Wang Y, Lei L. Peer relationship and adolescent smartphone addiction: the mediating role of self- esteem and the moderating role of the need to belong. J Behav Addict 2017; 6: 708-17.

[19] Yao MZ, He J, Ko DM, Pang K. The influence of personality, parental behaviors, and self-esteem on Internet addiction: a study of Chinese college students. Cyberpsychol Behav Soc Netw 2014; 17(2): 104-10.

Li C, Liu D, Dong Y. Self-Esteem and Problematic Smartphone Use among Adolescents: A Moderated Mediation Model of Depression and Interpersonal Trust. Front Psychol 2019; 10: 2872.

Shi X, Wang J, Zou H. Family functioning and Internet addiction among Chinese adolescents: The mediating roles of self-esteem and loneliness. Comput Hum Behav 2017; 76: 201-10.

Su B, Yu C, Zhang W, Su Q, Zhu J and Jiang Y. Father-Child Longitudinal Relationship: Parental Monitoring and Internet Gaming Disorder in Chinese Adolescents. Front Psychol 2018; 6(9): 95. 
ץ1 19 عوامل فردى و خانودگى در اعتياد به تلفن هوشمند

[23] Oosterhoff B, Palmer CA, Wilson J, Shook N. Adolescents' motivations to engage in social distancing during the COVID-19 pan- demic: Associations with mental and social health. $J$ Adolesc Health 2020; 67(2): 179-85.

[24] Yao MZ, Zhong ZJ. Loneliness, social contacts and Internet addiction: A cross-lagged panel study. Comput Hum Behav 2014; 30: 164-70.

[25] Sha P, Sariyska R, Riedl R, Lachmann B, Montag C. Linking internet communication and smartphone use disorder by taking a closer look at the Facebook and WhatsApp applications. Addict Behav Rep 2019; 9: 100148

[26] Zhang Y, Li S, Yu G. The relationship between loneliness and mobile phone addiction: A metaanalysis. Adv Psychol Sci 2020; 28(11): 1836-52.

[27] Lian Sh, Sun XJ, Niu GF, Yang XJ, Zhou ZK, Yang C. Mobile phone addiction and psychological distress among Chinese adolescents: The mediating role of rumination and moderating role of the capacity to be alone. J Affect Disord 2021; 279: 701-10.

[28] Gao J, Zheng P, Jia Y, Chen H, Mao Y, Chen S, et al. Mental health problems and social media exposure during COVID-19 outbreak. PLoS ONE 2020; 15: e0231924.

[29] Singh S, Dixit A, Joshi G. Is compulsive social media use amid COVID-19 pandemic addictive behavior or coping mechanism? Asian J Psychiatr 2020; 54; 102290.

[30] Klein R. Principles and practices of structural equation modeling. (4 ${ }^{\text {nd }}$ Eds). NewYork: Guilford Press; 2011.

P. 109.

[31] Epstein NB, Baldwin LM, Bishop DS. The McMaster Family Assessment Device. J Marital Fam Ther 1983; 9(2): 171-80.

Zolfaghari H, Seyedzadeh Dalooyi SI, Farrokhi H, Mostafapour V, Alishahi A, Mafi Asl S. Comparison of the Family Functions of Patients Feeding and Eating Disorders with Healthy Individuals Based on the McMaster Model. Mejds 2019; 8: 59-67. [Farsi] Jenaro C, Flores N, GomezVela M, Gonzalez-Gil F. Problematic Internet and cell- phone use: psychological, behavioral and health concerns. Addict Res Theory 2007; 15(3): 309-20.

[34] Golmohhamadian M, Yaseminezhad P. Normalization, Validity and Reliability of Cell-phone over-use scale among students. Journal of Psychology New Ideas 2011; 6(19): 37-52. [Farsi] Rosenberg M. Society and the adolescent self-image. NJ: Princeton University Press; 1965.p. 326.

[36] Leary MR. Sociometer theory and the pursuit of relational value: getting to the root of self-esteem. Europ Rev Soc Psychol 2005; 16: 75-111. 
[37] Attaran N, Mohammadi N. The mediating role of selfesteem in the relationship between Attachment Orientations and Psychological Adjustment. Journal of Developmental Psychology 2018; 15(58): 139-51. [Farsi]

[38] Russell D. UCLA Loneliness Scale (Version 3): Reliability, validity, and factor structure. J Pers Assess 1996; 66(1): 20-40.
[39] Khoshdel daryasari S, kord tamini B, kahrazee F. The Relationship of Homesickness with Loneliness and Attitude to communication with Opposite Sex in Non-local Students Living at Hostels of Sistan and Baluchestan University. Rooyesh 2019; 8 (5): 77-84. [Farsi] 
f 19 ا عوامل فردى و خانودگى در اعتياد به تلفن هوشمند

\title{
The Relationship between Family Functioning and Smartphone Addiction among Adolescents during the Coronaviruses Outbreak; the Mediating Role of Self-Esteem and Loneliness: A Descriptive Study
}

\author{
$\underline{\text { S. Zarei', Kh. Fooladvand }}{ }^{\Upsilon}$
}

Received: 28/08/21 Sent for Revision: 26/09/21 Received Revised Manuscript: 06/11/21 Accepted: 09/11/21

Background and Objectives: Studies have verified that family functioning has a negative relationship with smartphone addiction in adolescents. However, not much is known about the mediating mechanism underlying this relationship during the Coronaviruses Outbreak. Hence, the aim of the present study was to investigate the mediating role of self-esteem and loneliness in the relationship between family functioning and smartphone addiction.

Materials and Methods: The research design was descriptive. From the statistical population of male high school students at district 14 of Tehran in academic year of 2019-2020, a total of 281 students were selected using convenience sampling method. Data were collected using Family Assessment Device, UCLA Loneliness ScaleVersion 3, Cell-phone Over-use Scale, and Rosenberg Self- Esteem Scale. To analyze the data Pearson's correlation test and structural equation modeling were conducted.

Results: The results showed that direct effect of family functioning $(\beta=0.11, p<0.001)$, self-esteem $(\beta=0.27$, $\mathrm{p}<0.001)$, and loneliness $(\beta=0.23, \mathrm{p}<0.001)$ on the smartphone addiction were significant. Also, the results showed that the mediating role of self-esteem $(\beta=-0.11, p<0.01)$ and loneliness $(\beta=0.04, p<0.05)$ in the relationship between family functioning and smartphone addiction was significant.

Conclusion: This study revealed that the adolescents who live in better family atmosphere have higher self-esteem and experience less loneliness, and are less likely to develop smartphone addiction. Overall, these findings have some important implications for the prevention and intervention of the adolescent Internet addiction.

Key words: Smartphone Addiction, Family, Loneliness, Self-esteem, Adolescent

Funding: This study did not have any funds.

Conflict of interest: None declared.

Ethical approval: The Ethics Committee of Islamic Azad University, South Tehran Branch, approved the study (IR.IAU.STB.1399.015).

How to cite this article: Zarei $\mathrm{S}$, Fooladvand $\mathrm{Kh}$. The Relationship between Family Functioning and Smartphone Addiction among Adolescents during the Coronaviruses Outbreak; the Mediating Role of Self-Esteem and Loneliness: A Descriptive Study. J Rafsanjan Univ Med Sci 2022; 20 (11): 1179-94. [Farsi]

1- Assitant Prof. of Counseling, Psychology Dept., Lorestan University, Khorramabad, Iran, ORCID: 0000-0002-4627-4854 (Corresponding Author) Tel: (0663) 2721372, Fax: (0663) 2721372,E-mail: zarei.s@lu.ac.ir

2. Assitant Prof. of Psychology, Psychology Dept., Lorestan University, Khorramabad, Iran, ORCID: 0000-0001-6071-7036

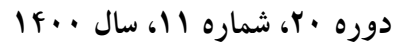

مجله دانشگاه علوم يزشكى رفسنجان 